\title{
Economics of Kharif tomato production in Latur district of Maharashtra
}

\section{R. D. SHELKE, R.V. CHAVAN AND M. M. BHOGAONKAR}

Received : 29.04.2013; Revised : 28.02.2016; Accepted : 30.03.2016

\begin{abstract}
Investigation was carried out during the year 2011-2012. Fifty Kharif tomato cultivators were selected from Chakur, Gharni, Wadwal, Mohanl and Kadmoli villages of Latur district for the present study. The techniques like mean, percentage, ratio and cost concept of Cost-A, Cost-B and Cost-C were used to analyze the data. The results revealed that per hectare gross returns from Kharif tomato was found to be Rs. 102099.43 net profit was Rs. 26309.71. The output-input ratio was 1.35. The per quintal cost of production in tomato was Rs. 332.60.
\end{abstract}

KEY WORDS : Tomato, Net profit, Cost-C, Gross returns

How to cite this paper: Shelke, R.D., Chavan, R.V. and Bhogaonkar, M.M. (2016). Economics of Kharif tomato production in Latur district of Maharashtra. Internat. J. Com. \& Bus. Manage, 9(1) : 77-79.

\section{MEMBERS OF THE RESEARCH FORUM}

Correspondence to:

R.D. SHELKE, Department of Agricultural Economics, College of Agriculture, Vasantrao Naik Marathwada Krishi Vidyapeeth, PARBHANI (M.S.) INDIA

Email: rds125@rediffmail.com

Authors' affiliations:

R.V. CHAVAN, Department of Agricultural Economics, College of Agriculture, Vasantrao Naik Marathwada Krishi Vidyapeeth, PARBHANI (M.S.) INDIA

M.M. BHOGAONKAR, Department of Agricultural Engineering, College of Agriculture (V.N.M.K.V.), LATUR (M.S.) INDIA 